\title{
КОНЦЕПТУАЛЬНІ ПІДХОДИ ДО ВИЯВЛЕННЯ СПЕЦИФІЧНИХ ОЗНАК НОВОЇ ІНДУСТРІАЛІЗАЦЇ̈ ПРОМИСЛОВОСТІ
}

\author{
Елена Акименко
}

\section{КОНЦЕПТУАЛЬНЫЕ ПОДХОДЫ К ВЫЯВЛЕНИЮ СПЕЦИФИЧЕСКИХ ПРИЗНАКОВ НОВОЙ ИНДУСТРИАЛИЗАЦИИ ПРОМЫШЛЕННОСТИ}

\author{
Olena Akymenko

\section{CONCEPTUAL APPROACHES TO THE IDENTIFICATION OF SPECIFIC} \\ FEATURES OF THE NEW INDUSTRIALIZATION OF INDUSTRY
}

У статті узагальнено науковий матеріал із досліджуваної теми, обтрунтовано ідею про необхідність $і$ значущзість нової індустріалізації-неоіндустріалізації, в основі якої покладено виробництво продукиії на базі найсучасніших інноваційних, інформаційних технологій і комп'ютерно-інтегрованих систем. Доведено необхідність ияього процесу для відродження вітчизняного промислового виробництва на нових інноваційних засадах, шуо можливе за рахунок гармонізаиії сочіально-економічних інтересів органів влади на всіх рівнях управління, бізнесу і громадськості. Наведено стратегічні напрямки державної політики у сфері модернізації економіки та підвищення конкурентоспроможності промисловості, реалізачія яких дозволить здійснити перехід від імітачійного до інновачійно-технологічного розвитку; побудувати динамічну, здатну до саморозвитку економіку; забезпечити ефективне використання всіх виробничих ресурсів суспільства; реалізувати інтелектуальний потенціал краӥни на основі розвитку науки та освіти. Розглянуто сучасні моделі індустріалізації з представленням їх класифікацій та ознак. Наведено схематичну інтерпретацію ключових етапів розвитку вітчизняної промисловості. Доведено необхідність становлення для Украӥни смартпромисловості - сучасної промисловості, заснованої на кіберфізичних та іниих авангардних технологіях.

Ключові слова: промислове виробництво; модернізація; неоіндустріалізація; розвиток; стратегія; державна промислова політика; зовнішньоекономічна політика; смартпромисловість.

Табл.: 1. Рис.: 3. Бібл.: 17.

В статье обобщен научный материал по исследуемой теме, обосновано идею о необходимости и значимости новой индустриализачии - неондустриализачии, в основе которой лежит производство продукиии на базе самьх современных инновационных, информационных технологий и компьютерно-интегрированных систем. Доказана необходимость данного процесса для возрождения отечественного промышленного производства на новых инновационных принципах, возможных на основе гармонизации социально-экономических интересов органов власти на всех уровнях управления, бизнеса и общественности. Приведены стратегические направления государственной политики в области модернизации экономики и повышения конкурентоспособности промышленности, реализация которых позволит осущчествить переход от имитационного к инновационно-технологическому развитию; построить динамическую, способную к саморазвитию экономику; обеспечить эффективное использование всех производственных ресурсов общества; реализовать интеллектуальный потенциал страны на основе развития науки и образования. Рассмотрены современные модели индустриализачии с представлением их классификации и признаков. Приведена схематическая интерпретация ключевых этапов развития отечественной промышленности. Доказана необходимость становления для Украины смарт-промышленности - современной промылиенности, основанной на киберфизических и других авангардных технологиях.

Ключевые слова: промышленное производство; модернизация; неоиндустриализация; развитие; стратегия; государственная промышленная политика; внешнеэкономическая политика; смарт-промышленность.

Табл. : 1. Рис.: 3. Библ.: 17.

The article summarizes the scientific material on the research topic, substantiates the idea of the need and importance of a new industrialization - neo-industrialization, which is based on the production of products based on the latest innovative, information technologies and computer-integrated systems. The necessity of this process for the revival of domestic industrial production on new innovative principles is proved, which is possible due to the harmonization of socio-economic interests of the authorities at all levels of government, business and the public.mThe strategic directions of the state policy in the field of modernization of economy and increase of competitiveness of the industry which realization will allow to carry out transition from imitation to innovation and technological development are resulted; to build a dynamic economy capable of selfdevelopment; to ensure the efficient use of all productive resources of society; to realize the intellectual potential of the country on the basis of the development of science and education. Modern models of industrialization with representation of their classifications and signs are considered. A schematic interpretation of the key stages of development of domestic industry is given. The necessity of becoming a smart industry for Ukraine - a modern industry based on cyberphysical and other advanced technologies has been proved.

Keywords: industrial production; modernization; neo-industrialization; development; strategy; state industrial policy; foreign economic policy; smart industry.

Table: 1. Fig.: 3. References: 17.

JEL Classification: $\mathrm{O} 14$

(C) Акименко О. Ю., 2020 
Постановка проблеми. Безумовна участь промисловості в підвищенні продуктивності суспільної праці, створенні нових високопродуктивних робочих місць та гідної зайнятості для молоді, генеруванні принципово нових можливостей, які відкриває перед людством сучасна, уже четверта, промислова революція, фундамент якої заклали розвиток кіберфізичних систем та злиття передових цифрових, фізичних і біологічних технологій, зумовлює вирішальну роль промисловості як основного драйвера економічного зростання країн.

Водночас гальмування розвитку промисловості продовжується і причиною цього процесу є синергія загальновизнаних показників : віддаленість держави від управління промисловим розвитком, незначний рівень виробництва, незадовільний рівень конкурентоспроможності, низький рівень підтримки експорту та його неприйнятна структура, небезпечний знос основних фондів, відділення промислового капіталу від банківсько-фінансового, лавиноподібний відтік кадрів, відсутність повноцінної інноваційної системи, недосконалість та неповнота нормативно-правового забезпечення [10].

Нині в жодного представника світової наукової спільноти не виникає сумнівів стосовно необхідності та значущості нової індустріалізації - неоіндустріалізації, в основі якої покладено виробництво продукції на базі найсучасніших інноваційних, інформаційних технологій і комп'ютерно-інтегрованих систем.

Не $\epsilon$ винятком і Україна, для якої проблема вибору наступного напряму розвитку промисловості стоїть найгостріше, з урахуванням критичності положення, в якому вона опинилась, та минулих можливостей одного з найбільших у Європі, на момент отримання Україною незалежності, розгалужених промислових комплексів. На жаль, відповідні умови промислового піднесення та формування фундаменту науковотехнологічного трансформування в поєднанні з економічним зростанням держави того періоду втрачені безповоротно. Реалізація принципу повноти структурного та інституційного складу, височезний рівень потужностей із випуску продукції, яка має збут, широта коопераційних зв'язків, науково-технологічне забезпечення розвитку, планомірне оновлення основних фондів, збалансованість продукції виробленої та споживаної, експорту та імпорту, необхідне фінансове забезпечення створювали потужний виробничий потенціал та задовольняли реалізацію принципу інноваційності. Україна по праву може пишатися минулостолітніми успіхами колективів учених, конструкторів, інженерів, робітників, які у складі колишнього СРСР створили найсучасніші технології, обладнання та виробництва в усіх сферах - від медицини до космосу, що давали можливість країні посідати провідні позиції у світі [10].

На сьогодні сучасний тип розвитку економіки країни експортно-сировинної орієнтації вже себе вичерпав, а ініційований інвестиційно-інноваційний тип розвитку має потребу у формуванні сучасного дизайну промислової політики та стратегічного планування процесів модернізації для побудови нової індустріалізації держави. Це означає, що вивести промисловість 3 нинішньої кризи окремими методами локального характеру не можливо.

Аналіз останніх досліджень і публікацій. $Є$ вагомі внески науковців у дослідженні процесів модернізації економіки та промислового сектору зокрема. Серед них наукові праці В. Гейця, С. Ілляшенка, Б. Квасюка, В. Семиноженка, Л. Федулової, В. Федоренко, А. Гриценка, В. Полтеровича та В. Попова, Е. Рустамова, в яких визначено вдалі умови безпосередньої реалізації проєкту модернізації, серед яких виділено опрацювання відповідної стратегії розвитку; факт існування зацікавлених груп інтересів із належним владним впливом, оперативність еліти та суспільства до суттєвих змін; впевненість у владі - «інституційна довіра».

Виділення недосліджених частин загальної проблеми. Проте, незважаючи на загальний високий рівень попередніх досліджень та спроби науковців визначити технологічні устрої, чинники, що визначають ефективну структуру промисловості та необхід- 
ТЕОРЕТИЧНІ ПРОБЛЕМИ РОЗВИТКУ НАЦІОНАЛЬНОЇ ЕКОНОМІКИ

ність у структурних зрушеннях економіки регіонів $[2 ; 5 ; 9 ; 14 ; 16]$, вбачаємо за необхідне окреслити комплексний підхід до вирішення проблеми індустріалізації промисловості, з огляду на соціально інклюзивний та екологічно відповідальний тип розвитку («розумний» розвиток), що грунтується на використанні штучного інтелекту та оновленні можливостей інформаційно-комунікаційних технологій.

Формування цілей статті. Головною метою цієї роботи є доведення необхідності нової індустріалізації для відродження вітчизняного промислового виробництва на основі нових інноваційних засад та становлення смартпромисловості, що вимагатиме гармонізації соціально-економічних інтересів органів влади на всіх рівнях управління, бізнесу та громадськості.

Виклад основного матеріалу. У сучасних наукових доробках термін «модернізація», який у перекладі з англійської мови визначається як «осучаснення», а в перекладі 3 французької - «новітній», трактується неоднаково й багатозначно, означаючи модифікацію, вдосконалення чого-небудь до нинішніх вимог, надання минулому не характерних йому сучасних ознак [4].

Використання цього терміна у двох аспектах: найперше, у технічному, прикладному - 3 метою вдосконалення об'єкта та приведення його у відповідність до нових технічних умов, вимог і норм та показників якості; після цього, в історико-філософському - 3 метою представлення макропроцесу переходу до модерного суспільства від традиційного, надає можливість представити модернізацію системним процесом вдосконалення відповідностей сучасним вимогам та скороченням відставання від конкурентів.

Однією з найважливіших особливостей модернізації економіки є втілення змін у національній економіці як структурних, технологічних, так і інституціональних, спрямованих на забезпечення конкурентоспроможності та подальший розвиток у довгостроковій перспективі [3].

Трактування модернізації як системний процес, спрямований на зміни політичних, правових, економічних, культурних інститутів та відносин, одночасно пов'язують іiі 3 мобілізаційним процесом, запровадженим для скорочення інтервалу відставання від країн-конкурентів та мобілізації необхідних ресурсів.

Згідно з поглядами науковців, модернізацію доцільно визначати за окремими напрямами, серед яких: модернізація традиційних галузей та спонукання високотехнологічних секторів до розвитку. Водночас виникають певні розбіжності щодо пропорційного розподілу ресурсів між ними. У свою чергу, сучасні підходи до основ модернізації базуються на теорії про стадії розвитку за П. Портером, на основі якої висувається припущення про обов'язковість проходження країною в процесі свого розвитку певних стадій і неможливість оминути («перескочити») жодну з них; кожна стадія розвитку потребує застосування адекватних інструментів і своєчасної їх зміни $[5 ; 12 ; 13 ; 15]$.

На думку Ю. Кінзерського та Е. Рустамова, розвитку економіки притаманні ресурсна, інвестиційна, інноваційна стадії. Крім того, А. Полтерович виділяє індустріалізацію експортноорієнтовану і стимулювання прискореного розвитку та стадію розвинутого ринку $[5 ; 12 ; 13 ; 17]$.

Аналіз досліджень наукових праць [3; 5; 15] дає підстави стверджувати, що модернізація - це багатовимірне та складне явище, яке потребує:

- акумуляції фінансових ресурсів шляхом підвищення рівня виконання державної політики модернізації економіки (у заданих напрямках - рис. 1) для побудови динамічної, здатної до саморозвитку соціально ефективної економіки;

- формування технічної стратегії держави для заволодіння потужним науковотехнічним потенціалом, здійснення інноваційного прориву в розвитку науки і техніки, забезпечення провідного місця у глобалізаційній економіці та на експортних ринках високотехнологічної продукції; 
- інтенсифікації процесу економічного відтворення шляхом поглиблення розподілу праці, ефективного використання енергетичного обладнання виробництва;

- розбудови країни в напряму повномасштабної неоіндустріалізації.

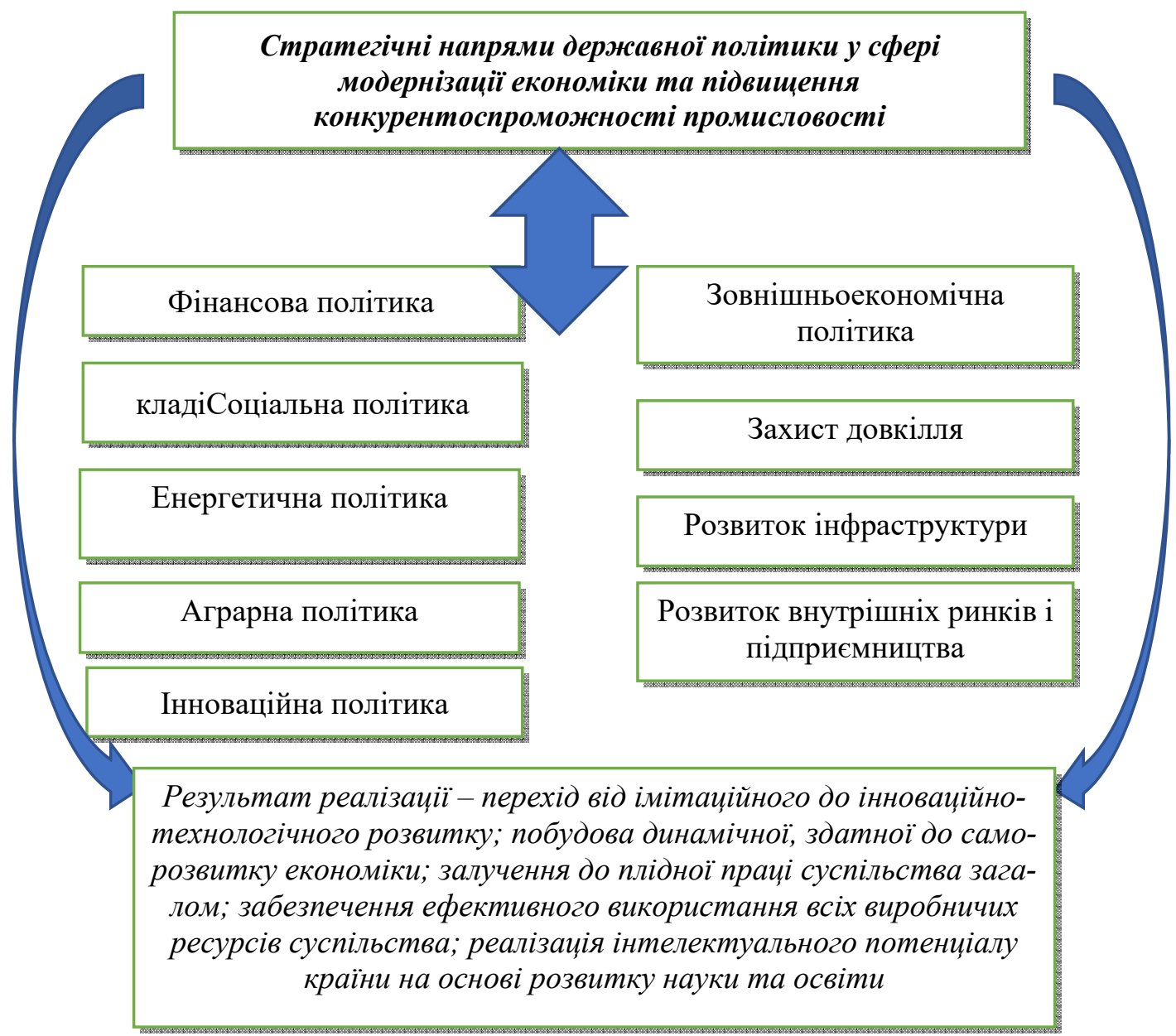

Рис. 1. Стратегічні напрями державної політики у сфері модернізачії економіки Джерело: побудовано авторкою на основі [3; 15].

Узагальнюючи цю проблему, Ю. Кіндзерський зазначає: «Реструктуризація промислового виробництва потребує відповідних взаємоузгоджених управлінських рішень, ресурсів і часу. Тому вона має здійснюватись на засадах державного стратегічного планування. Воно передбачає розробку системи довго-, середньо- та короткострокових прогнозів, визначення низки взаємопов'язаних цілей соціально-економічного і розвитку першого, другого і третього порядку, розроблення довгострокових концепцій, середньострокових програм та індикативних планів, створення інститутів організації і виконання намічених завдань, методів контролю та механізмів відповідальності за досягнення намічених результатів» [6].

Прийнято вважати неоіндустріалізацію явищем, здатним забезпечити налагодження нового розвитку продуктивних сил, маючи за основу високотехнологічні та науково місткі процеси виробництва та підгрунтя для цього - нове інституціональне середовище. Припущення про неоіндустріалізацію як процес, який має певну мету, методи, темпи, джерела та соціально-економічні наслідки, що потребують грунтовного дослідження, висуває В. П. Вишневський [2]. Наявні погляди щодо сучасних моделей індустріалізації можна класифікувати як «традиційну індустріалізацію», «некроіндустріалізацію», «постіндустріалізацію», «неоіндустріалізацію» (рис. 2) [8]. 
ТЕОРЕТИЧНІ ПРОБЛЕМИ РОЗВИТКУ НАЦІОНАЛЬНОЇ ЕКОНОМІКИ

\begin{tabular}{|c|c|}
\hline $\begin{array}{c}\text { «традиційна } \\
\text { індустріалізація» }\end{array}$ & $\begin{array}{l}\text { Характерними ознаками є переважання добувних галузей промисло- } \\
\text { вості, важкого та низькотехнологічного машинобудування } 3 \text { техно- } \\
\text { логіями переважно 3-го та 4-го укладів, які намагаються } 3 \text { метою } \\
\text { підтримки конкурентоспроможності, модернізуватися до ринкових } \\
\text { викликів сучасності }\end{array}$ \\
\hline «некроіндустріалізація & $\begin{array}{l}\text { Характерними ознаками для галузей промисловості з технологіями } \\
3 \text {-го та 4-го укладів, які переживають процеси деіндустріалізації } \\
\text { (перший тип), є скорочення виробничих потужностей внаслідок їх } \\
\text { фізичного зносу та відсутність ринкового попиту на продукцію }\end{array}$ \\
\hline «постіндустріалізація» & $\begin{array}{l}\text { Характерними ознаками є перехід до переважання технологій 5-го } \\
\text { укладу, який супроводжується процесами деіндустріалізації (другий } \\
\text { тип), виведення за межі країни низькотехнологічних галузей } \\
\text { (offshoring), введення сучасних високотехнологічних виробничих поту- } \\
\text { жностей, які орієнтовані на випуск продукції з високою часткою дода- } \\
\text { ної вартості, інформатизацією суспільства, розвитком сфери сучасних } \\
\text { наукоємних послуг }\end{array}$ \\
\hline «неоіндустріалізація» & $\begin{array}{l}\text { Характерними ознаками є перехід до технологій 6-го укладу, } 3 \\
\text { випуску продукції з високою доданою вартістю, який характери- } \\
\text { зується індивідуалізацією, наномініатюризацією, біотехно- } \\
\text { логізацією, когнітивізацією, розвитком 3D-друку шляхом реінду- } \\
\text { стріалізації (reshoring), тобто збільшення в національній економіці } \\
\text { робочих місць на базі цих технологій переважно у сфері малого та } \\
\text { середнього підприємництва }\end{array}$ \\
\hline
\end{tabular}

Рис. 2. Наявні погляди щзодо сучасних моделей індустріалізаџії

Джерело: побудовано авторкою на основі [8].

Вивчаючи досвід розвинених країн світу щодо здійснення структурних трансформацій, можемо зауважити, що більшість провідних країн через свою структурну політику прагнуть створити умови для зростання промисловості та конкурентоспроможності економіки [16]. Для України також випереджаючий розвиток промисловості має стати пріоритетним завданням всіх державних органів і структур України, керованого ними вітчизняного бізнесу, представників громадськості [10]. При цьому важливо враховувати вже наявний в цьому напрямі досвід із років незалежності України.

Отже, необхідно з'ясувати причини гальмування розвитку промисловості з урахуванням особливостей пройденого шляху (рис. 3) у руслі логіки пошуку пріоритетних напрямів та досягнення стратегічної мети реіндустріалізації України для створення конкурентоспроможного, інтегрованого у світову систему промислового сектору, показники якого відповідали б аналогам у промислово розвинених країнах.

Як уже вказувалося, для модернізації вітчизняної промисловості та її розбудови необхідна виважена промислова політика, під якою колектив науковців Інституту економіки та прогнозування НАН України пропонує розуміти державну політику, спрямовану на покращення бізнес-середовища або покращення структури економічної активності за секторами, технологіями, і яка забезпечить за рахунок втручання кращі перспективи для економічного зростання та суспільного добробуту в порівнянні з відсутністю такого втручання [14]. При тому, основними завданнями промислової політики є зрівноважування «провалів» ринку, вирішення проблем промислової організації, ініціювання структурних зрушень, впровадження органами державної влади всіляких інституційних заходів із покращення бізнес-середовища. 


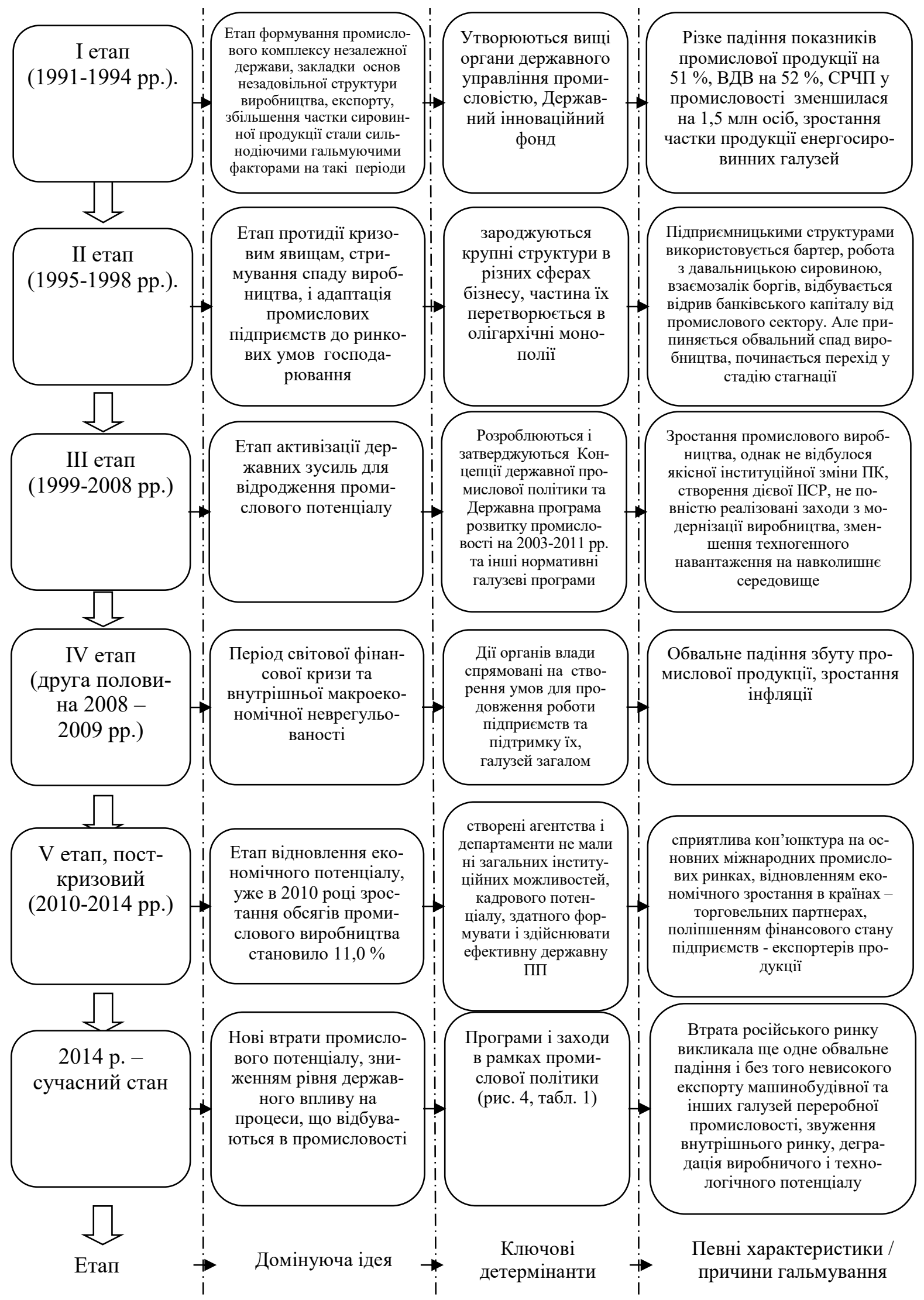

Рис. 3. Ретроспективний аналіз ключових етапів розвитку вітчизняної промисловості Джерело: побудовано авторкою на основі [10]. 
ТЕОРЕТИЧНІ ПРОБЛЕМИ РОЗВИТКУ НАЦІОНАЛЬНОЇ ЕКОНОМІКИ

Водночас суттю промислової політики є досягнення зазначених цілей за рахунок координації інструментів бюджетної, податкової, кредитно-грошової та митної політики. Програми та заходи, що були розроблені органами державної влади в рамках промислової політики України, згруповані та представлені в табл. 1.

Таблиця 1

Програми та заходи в рамках промислової політики Украӥни

\begin{tabular}{|c|c|c|c|c|}
\hline № & Нормативно-правовий документ & $\begin{array}{r}\Pi \\
\text { транс }\end{array}$ & $\begin{array}{l}\text { од } \\
\text { рмації }\end{array}$ & $\begin{array}{c}\text { Державна установа відповідальна } \\
\text { за розробку та реалізацію }\end{array}$ \\
\hline 1. & $\begin{array}{c}\text { Стратегія розвитку суднобудування } \\
\text { на період до } 2020 \text { року }\end{array}$ & 2009 & 2020 & $\begin{array}{l}\text { Мінекономрозвитку, } \\
\text { Мінінфраструктури }\end{array}$ \\
\hline 2. & $\begin{array}{c}\text { Стратегія розвитку аграрного сектору еко- } \\
\text { номіки на період до } 2020 \text { року }\end{array}$ & 2013 & 2020 & Мінагрополітики \\
\hline 3. & $\begin{array}{c}\text { Державна стратегія регіонального розвитку } \\
\text { на період до } 2020 \text { року }\end{array}$ & 2014 & 2020 & Мінекономрозвитку, Мінрегіон \\
\hline 4. & $\begin{array}{c}\begin{array}{c}\text { Комплексна програма розвитку фінансового } \\
\text { сектору України до } 2020 \text { року }\end{array} \\
\end{array}$ & 2015 & 2020 & НБУ, Мінфін, Мін’юст \\
\hline 5. & $\begin{array}{c}\text { Стратегія розвитку системи технічного } \\
\text { регулювання на період до } 2020 \text { року }\end{array}$ & 2015 & 2020 & Мінекономрозвитку, Мінрегіон \\
\hline 6. & $\begin{array}{c}\text { Стратегія сталого розвитку «Україна - } \\
2020 »\end{array}$ & 2015 & 2020 & $\begin{array}{c}\text { Президент України, Кабінет Мініст- } \\
\text { рів України, інші міністерства та } \\
\text { відомства }\end{array}$ \\
\hline 7. & $\begin{array}{c}\text { Стратегія реформування системи публічних } \\
\text { закупівель }\end{array}$ & 2016 & 2022 & $\begin{array}{c}\text { Мінекономрозвитку, Мінфін, } \\
\text { Мін’юст }\end{array}$ \\
\hline 8. & Стратегія подолання бідності & 2016 & 2020 & Мінсоцполітики \\
\hline 9. & $\begin{array}{c}\text { План заходів щодо дерегуляції } \\
\text { господарської діяльності }\end{array}$ & 2016 & ... & $\begin{array}{c}\text { Мінекономрозвитку, Мінінфрастру- } \\
\text { ктури, Мінсоцполітики, } \\
\text { Мінприроди, Мінрегіон }\end{array}$ \\
\hline 10 . & $\begin{array}{l}\text { Стратегія реформування системи управління } \\
\text { державними фінансами на 2017-2020 роки }\end{array}$ & 2017 & 2020 & Мінфін \\
\hline 11. & Експортна стратегія України & 2017 & 2021 & $\begin{array}{c}\text { Мінекономрозвитку, Міносвіти та } \\
\text { науки }\end{array}$ \\
\hline 12. & $\begin{array}{c}\text { Стратегія розвитку малого і середнього } \\
\text { підприємництва в Україні на період } \\
\text { до } 2020 \text { року }\end{array}$ & 2017 & 2020 & $\begin{array}{c}\text { Мінекономрозвитку, Мінсоцполіти- } \\
\text { ки, Мінфін, Мінрегіон, Мін’юст } \\
\text { тощо }\end{array}$ \\
\hline 13. & $\begin{array}{c}\text { Середньостроковий план пріоритетних дій } \\
\text { Уряду до } 2020 \text { року }\end{array}$ & 2017 & 2020 & Мінекономрозвитку \\
\hline 14. & $\begin{array}{c}\text { Енергетична стратегія України на період до } \\
2035 \text { року «Безпека, енергоефективність, } \\
\text { конкурентоспроможність» }\end{array}$ & 2017 & 2035 & Міненерго \\
\hline 15 . & $\begin{array}{c}\text { Стратегія розвитку оборонно-промислового } \\
\text { комплексу України на період до } 2028 \text { року }\end{array}$ & 2018 & 2028 & Мінекономрозвитку \\
\hline 16. & $\begin{array}{c}\text { Національна транспортна стратегія України } \\
\text { на період до } 2030 \text { року }\end{array}$ & 2018 & 2030 & Мінінфраструктури \\
\hline 17. & $\begin{array}{c}\text { Стратегія відродження вітчизняного } \\
\text { авіабудування на період до } 2022 \text { року }\end{array}$ & 2018 & 2022 & $\begin{array}{c}\text { Мінекономрозвитку, Міноборони, } \\
\text { Мінфін, МВС, Мінінфраструктури, } \\
\text { МЗС }\end{array}$ \\
\hline 18. & $\begin{array}{c}\text { Концепція Загальнодержавної цільової } \\
\text { науковотехнічної космічної програми } \\
\text { України на 2018-2022 роки }\end{array}$ & 2018 & 2022 & $\begin{array}{c}\text { Державне космічне агентство, Мін- } \\
\text { оборони }\end{array}$ \\
\hline 19. & \begin{tabular}{|c|} 
Основні засади (стратегія) державної \\
екологічної політики на період до 2030 року
\end{tabular} & 2019 & 2030 & Мінекології \\
\hline 20 . & $\begin{array}{l}\text { Проєкт Стратегії розвитку промислового } \\
\text { комплексу України на період до } 2025 \text { року }\end{array}$ & 2019 & 2025 & Мінекономрозвитку \\
\hline
\end{tabular}

Джерело: побудовано авторкою на основі [11;14]. 
Як свідчать результати дій держави в нормативно-правовому полі (табл. 1) та проведений нами аналіз синергетичних детермінант розвитку промислового виробництва, 3 огляду на визнання синергетики новітнім позитивістським підходом до вивчення будьякої відкритої системи з притаманними їй елементами самоорганізації і кібернетичного керування [1], фактичний стан справ у промисловій сфері держави ще не став гарантом підвищення рівня конкурентоспроможності економіки та національної безпеки держави. У зв'язку з цим вважаємо, що прискорення розвитку промисловості передбачається здійснити шляхом переходу на розвиток, орієнтований на знання та інновації, провідною ланкою якого стане смартпромисловість (Індустрія 4.0).

Безумовно, негативні явища, що відбуваються нині у вітчизняній промисловості, гальмуючи ії подальший розвиток, пов'язані як із суб' єктивними чинниками соціальноекономічного розвитку України, вразливістю національної економіки, так із несприятливою ситуацією на світовому ринку, спричинені такими обставинами:

- безпрецедентною руйнацією економіки тимчасово окупованих територій промислового регіону Донбасу;

- позбавленням збуту вітчизняної промислової продукції на традиційних ринках у зв'язку з розгортанням торговельної війни з РФ;

- незадовільним станом розвитку внутрішнього ринку промислової продукції;

- вимогливими домовленостями щодо національних промислових товаровиробників, що були визначені при укладанні Україною угоди про зону вільної торгівлі з СС;

- впливом синергії стандартизаційних обмежень (невідповідність технічних вимог і стандартів до продукції) та високого рівню конкуренції і торгового захисту на складність переорієнтації виробництва й експортних поставок на ринки розвинених країн;

- сукупними тенденціями посилення національних протекціоністських настроїв $\mathrm{i}$ тенденцій у світовій торгівлі за збереження Україною ліберального доступу на внутрішній ринок для продукції іноземного походження [7].

Отже, з огляду на втрачання концепцією постіндустріальної економіки своїх позицій, доцільним є твердження, що саме становлення смартпромисловості $є$ важливим кроком припинення гальмування промисловості України, 3 урахуванням головного драйвера революційних перетворень у світовій економіці та змін в ієрархічній структурі світових центрів сили - четвертої промислової революції, що заснована на розвитку кіберфізичних систем, злитті передових цифрових, фізичних і біологічних технологій.

Висновки та пропозиції. Закладаючи соціально інклюзивний та екологічно відповідальний тип розвитку («розумний» розвиток), що грунтується на використанні штучного інтелекту та оновленні можливостей інформаційно-комунікаційних технологій, обумовивши при цьому прискорений розвиток кіберфізичних виробничих систем і промисловий Інтернет речей, держава матиме магістральний шлях вирішення багатьох соціально-економічних проблем, накопичення науково-технічного потенціалу розвитку, визначення ії конкурентних позицій, як у сферах добробуту громадян, так і в забезпеченні національної безпеки країни. Дослідження напрямів підвищення рівня готовності промислового сектору України до смарттрансформацій буде об'єктом подальших наукових розвідок.

\section{Список використаних джерел}

1. Акименко О. Синергетичні детермінанти розвитку промислового виробництва в умовах обрання Україною курсу на євроінтеграцію. Проблеми і перспективи економіки та управління : науковий журнал. 2019. № 4 (20). С. 157-169.

2. Вишневский В. П. Глобальная неоиндустриализация и ее уроки для Украины. Экономика Украины. 2016. № 8. С. 26-43. 
ТЕОРЕТИЧНІ ПРОБЛЕМИ РОЗВИТКУ НАЦІОНАЛЬНОЇ ЕКОНОМІКИ

3. Геєць В. М., Семіноженко В. П. Інноваційні перспективи України. Харків : Константа, 2006. 272 c.

4. Енциклопедія інновацій / за ред. Р. Дяківа. Київ : Міжнародна економічна фундація, 2012.599 c.

5. Киндзерский Ю. Экономическое развитие и трансформация промышленной политики в мире: уроки для Украины. Экономика Украиньл. 2010. № 5. С. 4-5.

6. Кіндзерський Ю. В. Промисловість України: стратегія і політика структурно-технологічної модернізації : монографія. Київ, 2013. 536 с.

7. Князєв С. І. Становлення смарт-промисловості в Україні в умовах четвертої промислової революції : дис. ... д-ра екон. наук : спец. 08.00.03 «Економіка та управління національним господарством» / Інститут економіки промисловості НАН України. Київ, 2020. 514 с. URL: https://iie.org.ua/wp-content/uploads/2020/10/dysertatsiia_kniaziev-s.i._compressed.pdf.

8. Ляшенко В. I., Котов Є. В. Україна XXI: неоіндустріальна держава або «крах проекту»? : монографія. Київ, 2015. 196 с.

9. Модернізація економіки промислових регіонів України в умовах децентралізації управління : монографія / О. І. Амоша та ін. ; НАН України, Ін-т економіки пром-сті. Київ, 2018. 300 с.

10. Нова індустріалізація - реальний шанс для України. URL: https:/uspp.ua/assets/doc/ maket_nov_2019.pdf.

11. Офіційний вебпортал Верховної Ради України. URL: https:/www.rada.gov.ua.

12. Полтерович В. Гипотеза об инновационной паузе и стратегия модернизации. Bonpocbl экономики. 2009. № 6. С. 4-23.

13. Полтерович В., Попов В. Эволюционная теория экономической политики. Часть 1. Вопросы экономики. 2006. № 7. С. 4-20.

14. Промислова політика як ключовий інструмент стратегії розвитку : науково-аналітична доповідь / за ред. д-ра екон. наук Л. В. Дейнеко ; НАН України, ДУ «Ін-т екон. та прогнозув. НАН України». Київ, 2019. 143 с.

15. Рогоза М. Є., Кузьменко О. К. Модернізація економіки України у контексті неоіндустріальних перетворень України. Вісник економічної науки Украӥни. 2017. № 1(32). URL: https://core.ac.uk/download/pdf/87412054.pdf.

16. Розвиток промисловості для забезпечення зростання та оновлення української економіки : науково-аналітична доповідь / за ред. д-ра екон. наук Л. В. Дейнеко ; НАН України, ДУ «Ін-т екон. та прогнозув. НАН України». Київ, 2018. 158 с.

17. Рустамов Э. Принципы эволюционной модернизации переходных экономик. Bonpocbl экономики. 2009. № 7. С. 85-96.

\section{References}

1. Akymenko, O. (2019). Synerhetychni determinanty rozvytku promyslovoho vyrobnytstva v umovakh obrannia Ukrainoiu kursu na yevrointehratsiiu [Synergetic determinants of industrial production development in the conditions of the Ukraine's European integration course]. Problemy $i$ perspektyvy ekonomiky ta upravlinnia - Problems and prospects of economics and management, 4(20), pp. 157-169.

2. Vishnevskii, V. P. (2016). Globalnaia neoindustrializatsiia i ee uroky dlia Ukrainy [global neoindustrialization and its lessons for Ukraine]. Ekonomika Ukrainy - Economy of Ukraine, (8), pp. 26-43.

3. Heiets, V. M., Seminozhenko, V. P. (2006). Innovatsiini perspektyvy Ukrainy [Innovative prospects of Ukraine]. Konstanta.

4. Diakiv, R. (Ed.). (2012). Entsyklopediia innovatsii [Encyclopedia of Innovation]. Mizhnarodna ekonomichna fundatsiia.

5. Kindzerskii, Iu. (2010). Ekonomicheskoe razvitie i transformatsiia promyshlennoi politiki v mire: uroky dlia Ukrainy [Economic development and transformation of industrial policy in the world: lessons for Ukraine]. Ekonomika Ukrainy - Economy of Ukraine, 5. pp. 4-5.

6. Kindzerskyi, Yu. V. (2013). Promyslovist Ukrainy: stratehiia $i$ polityka strukturnotekhnolohichnoi modernizatsii [Industry of Ukraine: strategy and policy of structural and technological modernization]. 
7. Kniaziev, S. I. Stanovlennia smart-promyslovosti v Ukraini v umovakh chetvertoi promyslovoi revoliutsii [Formation of smart industry in Ukraine under the conditions of the Fourth industrial revolution] [PhD dissertation, Instytut ekonomiky promyslovosti NAN Ukrainy]. https://iie.org.ua/wpcontent/uploads/2020/10/dysertatsiia_kniaziev-s.i._compressed.pdf.

8. Liashenko, V. I., Kotov, Ye. V. (2015). Ukraina XXI: neoindustrialna derzhava abo «krakh proektu»? [Ukraine XXI: neo-industrial state or "project collapse"?].

9. Amosha, O. I. and others. (2018). Modernizatsiia ekonomiky promyslovykh rehioniv Ukrainy $v$ umovakh detsentralizatsii upravlinnia [Modernization of the economy of industrial regions of Ukraine in terms of decentralization of management].

10. Nova industrializatsiia - realnyi shans dlia Ukrainy [New industrialization is a real chance for Ukraine]. https://uspp.ua/assets/doc/maket_nov_2019.pdf.

11. Ofitsiinyi vebportal Verkhovnoi Rady Ukrainy [Official web portal of the Verkhovna Rada of Ukraine]. https://www.rada.gov.ua.

12. Polterovych, V. (2009). Hypoteza ob ynnovatsyonnoi pauze y stratehyia modernyzatsyy [The hypothesis of an innovative pause and modernization strategy]. Voprosy ekonomiki - Issues of economics, (6), pp. 4-23.

13. Polterovych, V., Popov, V. (2006). Evoliutsionnaia teoriia ekonomicheskoi politiki. Chast 1 [Evolutionary theory of economic policy. Part 1]. Voprosy ekonomiki - Issues of economics, (7), pp. 4-20.

14. Deineko, L. V. (2019). Promyslova polityka yak kliuchovyi instrument stratehii rozvytku: naukovo-analitychna dopovid [Industrial policy as a key tool of development strategy: scientific and analytical report].

15. Rohoza, M. Ye., Kuzmenko, O. K. (2017). Modernizatsiia ekonomiky Ukrainy u konteksti neoindustrialnykh peretvoren Ukrainy [Modernization of Ukraine's economy in the context of neoindustrial transformations of Ukraine]. Visnyk ekonomichnoi nauky Ukrainy - Bulletin of Economic Science of Ukraine, (1(32)). https://core.ac.uk/download/pdf/87412054.pdf.

16. Deineko, L. V. (2018). Rozvytok promyslovosti dlia zabezpechennia zrostannia ta onovlennia ukrainskoi ekonomiky: naukovo-analitychna dopovid [Development of industry to ensure the growth and renewal of the Ukrainian economy: scientific and analytical report].

17. Rustamov, E. (2009). Pryntsipy evoliutsionnoi modernizatsii perekhodnykh ekonomik [Principles of evolutionary modernization of transition economies]. Voprosy ekonomiki - Issues of economics, (7), pp. 85-96.

Акименко Олена Юріївна - кандидат економічних наук, доцент, доцент кафедри бухгалтерського обліку, оподаткування та аудиту, Національний університет «Чернігівська політехніка» (вул. Шевченка, 95, м. Чернігів, 14035, Україна).

Акименко Елена Юрьевна - кандидат экономических наук, доцент, докторант кафедры бухгалтерского учета, налогообложения и аудита, Национальный университет «Черниговская политехника» (ул. Шевченко, 95, г. Чернигов, 14035, Украина).

Akymenko Olena - PhD in Economics, Associate Professor, Associate Professor The Department of Accounting, Taxation and Audit Chernihiv Polytechnic National University (95 Shevchenka Str, 14035 Chernihiv, Ukraine.)

ORCID: https://orcid.org/0000-0002-0323-5978

ResearcherID -G-9876-2016 